\title{
Comparative Analysis of Project and Demonstration Teaching Methods in Improving Students' Academic Achievement in Basic Electricity in Technical Colleges
}

\author{
Titus Iloduba Eze a, * (D), Chibueze Nweke Nwalo b (D), David Agwu Udu c (D) \\ a Department of Technology \& Vocational Education, Nnamdi Azikiwe University, Awka, Nigeria. \\ b Department of Vocational \& Technical Education, Alex Ekwueme Federal University, Ndufu-Alike, Ebonyi State, Nigeria. \\ c Department of Science Education, Alex Ekwueme Federal University, Ndufu-Alike, Ebonyi State, Nigeria. \\ *Corresponding author email: tylodubaeze@yahoo.com \\ DOI: https://doi.org/10.34256/ajir2124
}

Received: 26-02-2021

Revised: 25-04-2021

Accepted: 28-04-2021

Published: 10-05-2021

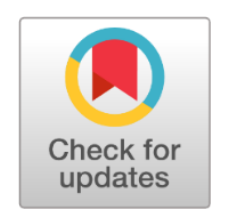

Abstract: This study determined the comparative analysis of project and demonstration teaching methods in improving students' academic achievement in basic electricity in technical colleges. The study adopted quasiexperimental design; specifically, pre-test, post-test for non-randomized and unequal groups were used. One research question guided the study and one hypothesis was tested at 0.05 level of significance. Four technical colleges in Ebonyi State, each technical college offering basic electricity, were used. A total of 141 Technical College year II (TC II) students formed the population of the study. The instruments used in the study were Basic Electricity Achievement Test (BEAT), Project Method Instructional Manual (PMIM) and Demonstration Method Instructional Manual (DMIM), which were validated by three experts. The instrument (BEAT) was administered twice to twenty (20) TC11 students in Enugu State and Pearson's Product Moment Correlation was used to obtain a reliability index of 0.89 . Data collected for the study were analyzed using mean and standard deviation for research question, while the hypothesis was tested using Analysis of Covariance (ANCOVA). The study found more improvement in students' academic achievement when taught basic electricity using project teaching method than when taught using demonstration teaching method. The study therefore showed that project teaching method was more effective than demonstration teaching method in enhancing students' academic achievement in basic electricity. The researchers therefore recommended among other things that teachers should embrace project teaching method more than demonstration teaching method to enhance students' academic achievement in basic electricity.

Keywords: Basic Electricity, Demonstration Teaching Method, Students' Academic Achievement, Project Teaching Method, Technical Education.

\section{Introduction}

Technical education is designed for skill acquisition and skill development. It aims at equipping the students with the requisite skills and knowledge for industrial production and self-reliance. Technical education according to (Federal Republic of Nigeria, FRN, 2014), is the aspect of educational process that involves the study of technologies and related sciences and the acquisition of practical skills, understanding, and knowledge relating to 
occupations in various sectors of economic and social life. Contributing, (Ojimba, 2012) saw technical education as education geared towards teaching of technical skills and attitudes suitable for individuals to become technicians in specific occupations. Technical education puts into consideration the interest, needs, attributes and abilities of the learners in the learning process. Meanwhile, one of the major courses taught in technical education is basic electricity.

Basic electricity is one of the core electrical technology trade courses that provides students with the basic scientific knowledge and practices in the fields of electrical and electronics at all levels of education. (Robinson, 2017) explained that basic electricity is the bedrock of all technological subjects, and also the key to the industrial development of any nation, since industries cannot function without electricity. The objectives of basic electricity as outlined in the National Business and Technical Examination Board, NABTEB, (2019), syllabus are, among other things to equip students with knowledge and understanding of the basic concepts and principles of basic electricity. Included in the basic electricity concepts are the ability to use tools and equipment in the maintenance as well as repair of electrical/electronic devices; the understanding of the principle of operation and the application of simple electrical/electronic devices; and the understanding of safe working procedures and safety precautions in domestic and industrial installation. Thus, students' proficiency in basic electricity courses could contribute immensely in industrial production and technological advancement of the nation.

Despite the importance of basic electricity in industrial production and technological development of the society, there has been low academic achievement of students in the subject in technical colleges in Nigeria and particularly in Ebonyi State (Bala, 2006; Ogbu, 2011; Robinson, 2017).
Specifically, the 2010-2017 NABTEB results for Ebonyi State revealed high failure rate of students in basic electricity by percentage failure indices of $54.63 \%, 62.81 \%, 59.22 \%$, $53.20 \%, 70.16 \%, 55.80 \%, 63.79 \%$ and $58.27 \%$ for the respective years (Exams office, Ebonyi State Ministry of Education, Abakaliki, 2018). This position was further clarified by the report of NABTEB Chief Examiner's (2012). The report showed that about 47.4 percent of basic electricity candidates who sat for the examination in May/June 2012 passed at credit level across the country. Furthermore, the study conducted by (Joshua, 2015) revealed that some students who chose basic electricity were unable to demonstrate what they learnt in classroom setting. Meanwhile, the problem of students' low academic achievement in basic electricity has raised considerable questions attributable to various factors such as ineffective teaching methods in basic electricity, teachers' attitude towards teaching basic electricity, number of students per class and unavailability of instructional facilities (Ogbu, 2010; Olatoye \& Adekoya, 2010; Dorgu, 2015). Similarly, NABTEB Chief Examiner's report (2012) identified that students' low practical experiences were associated with ineffective teaching methods and thus recommended that teachers should use teaching methods that expose students to practical experiences in the laboratories to improve their academic achievement in basic electricity. The report therefore called for teachers to use teaching methods that involve students in activities by using student-centered and activity-based teaching strategies/methods, so as to enhance the students' academic achievement in basic electricity.

(Ayonmike, 2014) described teaching strategies/methods as those processes and strategies teachers employ to equip students with the appropriate and functional skills in an environment to enable them function effectively in meeting the needs of the society. Continuing, Ayonmike added that the way and 
manner teachers teach their students in order to achieve the stated objective of the lesson could also be referred as teaching method. Teaching methods are generally used to foster students' participation in learning activities, provide the sense of reasonability and direct application of learning principles to the achievement of stated educational objectives. Teaching methods help teachers to impart the basic scientific knowledge, trade theories and practices that could improve students' creativity in basic electricity. Appropriate teaching methods could promote the use of technologies to enhance students' learning of basic electricity concepts, thereby facilitating students' learning and satisfaction (Dorgu, 2015). Furthermore, Amaechi and (Thomas, 2016) affirmed that a good teaching method for skill acquisition must possess qualities capable of bringing out the students' innovative abilities. This entails that proper selection of teaching methods could help teachers to accomplish specific goals in subject areas such as basic electricity (Kennedy, 2011). Therefore, any teaching method to be adopted in teaching basic electricity must be effective in promoting the acquisition of skills and knowledge to enhance students' understanding of the subject.

Several teaching methods abound, for instance project and demonstration teaching methods and these methods acknowledge students' participatory role in teaching and learning processes (Okafor, 2014). However, one of these two methods could be more effective than the other in enhancing students' academic achievement in basic electricity. Therefore, the comparative analysis of project and demonstration teaching methods in improving students' academic achievement in basic electricity in technical colleges becomes imperative.

Project teaching method involves the processes of assigning a particular work to students or group of students to work on at their own pace and provide feedback to the teacher. Olatoye and (Adekoya, 2010) defined project teaching method as a systematic teaching method that engages students in knowledge and skills acquisition through an extended inquiry process structured around complex, authentic questions and carefully designed procedures and tasks. In this case, the students are independent learners who can supplement the formal classroom teaching with other activities that will improve their understanding. Similarly, (Sola and Ojo, 2007) asserted that project teaching method allows students occasionally to define the problem, plan the work, find appropriate resources, carry out the plans and draw conclusion. In general, project teaching method engages students in the learning process and allows for students' practical application of theoretical knowledge to solve real life problems. The study conducted by (Borich, 2011) opined that project-based instructional strategy provides excellent ways to impart adequate skills, knowledge and competencies needed to enhance students' academic achievement. Furthermore, the study conducted by (Biajone, 2006) posited that project work motivates both the teacher and students to develop cooperative work intended to make students to perceive and understand all the necessary stages required to arrive at a desired learning objectives. This can be compared with the demonstration teaching method.

Demonstration teaching method is a teaching strategy that provides opportunities for teachers to combine discussion and explanation to enhance students' understanding of the concept being taught (Basheer, Hugerat, Kortam, \& Hofstein, 2016). (Umar, 2013) defined demonstration teaching method as a teaching strategy used in technical and training colleges aimed at achieving the psychomotor and cognitive objectives of learning. Demonstration method could be used to teach concepts and principles of the real thing, by combining explanation with handling or manipulation of real things, materials and equipment, which can enhance students' understanding of the concepts (Akinbobola \& 
Iktde, 2011). Furthermore, demonstration teaching strategy allows two-way communication in which the teacher communicates with the students and the students also communicate with their teacher, and because it has a considerable portion of practical work, it can provide concrete experiences to students. It implies that demonstration teaching method allows students to learn various scientific methods and techniques, and how to operate various equipment in the laboratory. When teachers employ demonstration in their teaching, it could promote students' concentration, skill acquisition through repetition and enhance reasoning faculty that will promote their understanding of various concepts (Himanshu, n. d.). According to (Price and Brooks, 2012), demonstration teaching method improves students' performance on practice, assignment, laboratory investigation and examination, as well as enhances students' understanding of concepts. Demonstration teaching method allows the students to perceive themselves as having the ability, knowledge and prerequisite skills necessary for learning. Demonstration teaching method should be planned in advance and in sequence and should allow students to follow the steps demonstrated by the teachers (Muhammad, Bala \& Ladu, 2016). It entails that the students are to repeat and practice the procedures in order to reinforce the learning process. The teacher corrects students' mistakes and reinforces proper procedures. Demonstration teaching method could be done online with the use of internet (Ikitde \& Edet, 2013). Demonstration teaching method could be successfully implemented at the technical college level with limited time and money and could also help to ensure effective instructional delivery. Therefore, when demonstration teaching method is applied to teach basic electricity, it could cover the drawbacks or limitations found in lecture teaching method. It is evident from the foregoing discussions that project and demonstration teaching methods could have significant impact on students' academic achievement and if properly applied in teaching basic electricity, there could improve students' academic achievement in basic electricity.

On the other hand, academic achievement has to do with attainment of set objectives of instruction (Nbina \& Obomanu, 2011). Continuing, Nbina and Obomanu added that academic achievement is generally used to determine how well an individual was able to assimilate, retain, recall and communicate knowledge of what has been learnt. In their own views, (Kpolovie, Joe and Okoto, 2014) opined that the ability of the students to study and remember facts, and being able to communicate the knowledge orally or in written form even in an examination condition indicates the level of academic achievement of such students. More so, (Horvath, 2011) stated that academic achievement is student's achievement on a standard measurement such as achievement test, skills tests, and analytical test. (Saka-Alikinla, Owodunni and Babatunde, 2016) maintained that academic achievement test is often constructed and standardized with a view to measure proficiency of learners in different subjects. The academic achievement of students in basic electricity indicates the performance of students in basic electricity as represented by scores or marks on an achievement test. (Maizuwo, 2011) investigated the effectiveness of teaching strategies on students' academic achievement in organic chemistry and found a significant difference in students' academic achievement based on teaching strategies. Furthermore, (Leeds et al. 2013) affirmed that teaching method is an important predictor of students' academic achievement in technical subjects. From the foregoing, it can be established that students' academic achievement varies from one teaching method to the other. For instance, (Animezie, 2015) affirmed that constructivist instructional methods are more effective in enhancing students' academic achievement in physics than the conventional teaching method. These affirm the fact that academic 
achievement of students in basic electricity could be greatly affected by teaching methods utilized by teachers.

However, (Eze, Ezenwafor and Molokwu, 2015) affirmed that teachers in technical colleges always use conventional teaching methods like lecture teaching method which has been found to frustrate students and creates learning difficulties. In the same view, (Okafor, 2014) summited that the conventional teaching method, like lecture method, is a key contributing factor to students' low academic achievement in basic electricity. Furthermore, the conventional teaching method is not innovative enough to provide adequate practical experiences needed by students in basic electricity. It is evident from the above that students' academic achievement in basic electricity can improve if teachers change their teaching approach to more innovative and effective teaching strategies (Zakaria, Chine \& David, 2015). Over the years, all efforts to address students' challenges, improve their academic achievement, motivate them to learn and develop the competency needed for the world of work using various teaching methods seem not to have been achieved (Okafor, 2014; Eze, et al., 2015). It is therefore pertinent to apply some other instructional strategies, specifically, project and demonstration methods in teaching basic electricity to compare their effectiveness in enhancing students' academic achievement in order to prepare them for the societal and industrial needs.

\section{Purpose of the study}

This study compared the effectiveness of project and demonstration teaching methods in improving students' academic achievement in basic electricity in technical colleges. Specifically, the study compared:

the mean academic achievement scores of students taught basic electricity using project teaching method and those taught using demonstration teaching method.

\section{Research Question}

The study was guided by a research question:

What are the mean academic achievement scores of students taught basic electricity using project teaching method and those taught using demonstration teaching method?

\section{Hypothesis}

One null hypothesis was tested at 0.05 level of significance.

There is no statistically significant difference in the mean academic achievement scores of students taught basic electricity using project teaching method and those taught using demonstration teaching method.

\section{Materials and Method}

The study adopted quasi-experimental design. Specifically, pre-test, posttest, for nonrandomized and unequal groups were used. One research question guided the study and one hypothesis was tested at 0.05 level of significance. Four technical colleges in Ebonyi State, each technical college offering basic electricity were used. One hundred and forty one (141) Technical College year II (TC II) students offer basic electricity in technical colleges in Ebonyi State. The entire population was used for the study, since the population was small and manageable. Simple random sampling (balloting) was used to assign two intact classes to Project Method Group and the other two intact classes to demonstration method group. Project method group comprised of 75 students, while demonstration method group comprised of 66 students. 
The Instruments used for the study were the Basic Electricity Achievement Test (BEAT), Project Method Instructional Manual (PMIM), and Demonstration Method Instructional Manual (DMIM). The instruments were developed by the researchers based on the content areas in basic electricity, which includes; conductors and insulators, electric current and potential difference, resistance, capacitors and capacitance. The table of specifications was used to allocate questions to content areas. BEAT consisted of two sections A and B. Section A elicited the background information of the students, while section $B$ was a multiple-choice test comprising of 50items with four options (A - D) per item adapted from NABTEB and WAEC past questions from 2005-2018.

The face and content validity of the instruments were ascertained by three experts; two from Technology Education programme, and one from Measurement and Evaluation unit, Nnamdi Azikiwe University, Awka. The recommendations, suggestions and corrections where appropriate were used to modify the final copies of the instruments. The reliability of the BEAT was established using a test- retest method in which the instrument was administered twice to twenty (20) TC11 students in Enugu State and Pearson's Product Moment Correlation was used to compute the reliability coefficient which yielded an index of 0.89. Project Method Instructional Manual (PMIM) was a set of lesson plans based on project teaching method, whereas, the Demonstration Method Instructional Manual (DMIM) was a set of lesson plans based on demonstration teaching method.

Before the commencement of the experiments, the researchers took permission from the school authorities to involve staff and students in the study and a 2-day training conference was organized for the teachers on the use of project method instructional manual and demonstration method instructional manual. The teachers were exposed to detailed explanations on the use of project and demonstration teaching methods and other research expectations. The training programme was based on the aims and objectives of the research, the topics to be taught, use of lesson plans/manuals, the method of administration of Basic Electricity Achievement Test (BEAT) and general conduct of the study.

Moreover, the study took place during the normal school lesson periods. The normal time-tables of the schools were strictly followed during the study. The regular school basic electricity teachers were used as research assistants. The students involved in the study were within the same age bracket and academic ability. They were also the prospective candidates for NABTAB and WAEC examinations.

On the first week, before the lessons commenced, the instrument (BEAT) was administered as pre-test to the two groups after which the proper teaching commenced by using the prepared instructional manuals/lesson plans. The two groups were taught the selected topics by the research assistants who were the regular class teachers, using project and demonstration teaching techniques. The teaching lasted for four weeks, after which the post-test was administered and their scores recorded. The content of BEAT was reshuffled and the colour of the paper changed each time the BEAT was used for data collection. The academic achievements of students were determined in terms of mean scores and mean gain. Differences in the posttest mean scores and pre-test mean scores indicate academic achievement mean gain. Furthermore, the research question was answered using mean with standard deviation, while, the null hypothesis was tested at 0.05 level of significance using Analysis of Covariance (ANCOVA). The scores obtained from both groups were compared to determine if there was any significant difference in the two 
methods on students' academic achievement in basic electricity.

\section{Results}

Research Question: What are the mean academic achievement scores of students taught basic electricity using project teaching method and those taught using demonstration teaching method?

The results of data analysis presented in table 1 above reveals that students taught basic electricity using project teaching method had pre-test mean score of 32.80 with a standard deviation of 4.59, and a post-test mean score of 73.47 with a standard deviation of 9.14, whereas, those taught using demonstration teaching method had pre-test mean score of 32.88 with a standard deviation of 5.07, and a post-test mean score of 66.00 with a standard deviation of 7.27. The table shows that the group taught with project teaching method had mean gain score of 40.67 which is relatively higher than 33.12 mean gain score obtained in those taught with demonstration teaching method. However, the table did not show whether the observed difference in the mean academic achievement scores of students taught using project teaching method and those taught using demonstration teaching method was statistically significant or can be attributed to error variance. In order to determine the significance or otherwise of the observed differences, the results were subjected to inferential testing as shown in hypothesis 1 .

Table 1. Mean and Standard Deviation of Students' Scores in Project and Demonstration Teaching Methods.

\begin{tabular}{|c|c|c|c|c|c|}
\hline $\begin{array}{c}\text { Teaching } \\
\text { Method }\end{array}$ & $\begin{array}{c}\text { No. Of Subjects } \\
\text { (N) }\end{array}$ & $\begin{array}{c}\text { Test } \\
\text { Type }\end{array}$ & $\begin{array}{c}\text { Mean } \\
\text { (X) }\end{array}$ & $\begin{array}{c}\text { Standard Deviation } \\
\text { (SD) }\end{array}$ & $\begin{array}{c}\text { Gain } \\
\text { Score }\end{array}$ \\
\hline \multirow{2}{*}{ Project } & 75 & Pre-test & 32.80 & 4.59 & 40.67 \\
& Post-test & 73.47 & 9.14 & \\
\hline \multirow{2}{*}{ Demonstration } & \multirow{2}{*}{66} & Pre-test & 32.88 & 5.07 & 33.12 \\
& Post-test & 66.00 & 7.27 & \\
\hline
\end{tabular}

Table 2. ANCOVA of students' Academic Achievement Scores in Project and Demonstration Teaching Methods.

\begin{tabular}{|l|l|l|l|l|c|}
\hline \multicolumn{1}{|c|}{ Dependent Variable: } & \multicolumn{1}{l|}{ POSTTEST } \\
\hline Source & $\begin{array}{c}\text { Type III Sum of } \\
\text { Squares }\end{array}$ & \multicolumn{1}{c|}{ Df } & Mean Square & \multicolumn{1}{c|}{ F } & Sig. \\
\hline Corrected Model & 2961.309 a & 4 & 740.327 & 11.688 & .000 \\
\hline Intercept & 7936.174 & 1 & 7936.174 & 125.290 & .000 \\
\hline PRETEST & 954.862 & 1 & 954.862 & 15.075 & .000 \\
\hline METHOD & 1652.316 & 1 & 1652.316 & 26.085 & .000 \\
\hline Error & 8614.578 & 136 & 63.342 & & \\
\hline Total & 701916.000 & 141 & & & \\
\hline Corrected Total & 11575.887 & 140 & & & \\
\hline
\end{tabular}


Hypothesis: There is no statistically significant difference in the mean academic achievement scores of students taught basic electricity with project teaching method and those taught using demonstration teaching method.

Table 2 shows that at 0.05 level of significance, the value of F-calculated is 26.085 with p-value of .000 which is less than 0.05 . The hypothesis is therefore rejected. This means that there was significant difference in the mean academic achievement scores of students taught basic electricity using project teaching method and those taught using demonstration teaching method. This implies that the observed difference in the students' academic achievement taught using both project teaching method and demonstration teaching method was significant which cannot be attributed to error variance. With this result and the one shown in table 1 above, it could be deduced that both project and demonstration teaching methods improved students' academic achievement as shown in the difference in the pre-test and post-test mean academic achievement scores. However, project teaching method had higher mean academic achievement score than demonstration teaching method, suggesting that project teaching method was relatively more effective in enhancing students' academic achievement in basic electricity than demonstration teaching method.

\section{Discussion of Findings}

The findings of the study revealed that project teaching method is relatively more effective than demonstration teaching method in improving students' academic achievement in basic electricity. This was further confirmed by the fact that this study found a statistically significant difference in the mean academic achievement scores of students taught basic electricity using project teaching method and those taught using demonstration teaching method. This finding is in agreement with
(Borich, 2011); (Thompson and Soyibo, 2012); and (Nsa, 2002), who found that project teaching method is relatively more effective than demonstration teaching method in enhancing students' academic achievement in social studies, chemistry and agricultural Science respectively. The finding was further supported by (Andiema, 2016), who reported that project teaching method is highly effective in enhancing students' achievement as it promotes students' ability to experiment, classify, observe, and use hands-on tools to differentiate natural features within the environment. In addition, the findings of this study is in line with (Olatoye and Adekoya 2010); (Bako, 2017) who posited that there was significance difference in students' mean academic achievement scores in project and demonstration teaching methods, and that project teaching method was significantly better on students' academic achievement than demonstration teaching method. Furthermore, the study conducted by (Pavaloic, Petrescu and Dragomirescu, 2014) found that project teaching method provides an effective and enjoyable way for students to learn and also develop deeper learning competencies required for the advancement in the field of study. In project teaching method, students observe, experiment, classify and discover facts on their own, hence, more effective than demonstration teaching method in enhancing students' academic achievement.

\section{Conclusion}

Learning basic electricity leads to the development of creative reasoning and the understanding of other related science subjects. Project teaching method has the capacity to develop students' ability to think critically and analytically to solve problems. The project and demonstration teaching methods used in this study produced significantly better performance for students in basic electricity. However, the study revealed that project teaching method was relatively 
more effective than demonstration teaching method in enhancing students' academic achievement in basic electricity. Furthermore, when project and demonstration teaching methods were applied to teach basic electricity, there afforded the students the opportunity to study on their own. The study concludes that project teaching method is a more effective teaching method for teaching basic electricity in technical colleges.

\section{Recommendations}

Based on the findings of this study, the researchers made the following recommendations:

1. Teachers should embrace project teaching method more than demonstration teaching method to enhance students' academic achievement in basic electricity.

2. Curriculum planners should include project teaching method as a teaching strategy for basic electricity.

3. Government and private technical colleges should employ teachers who know the basic electricity content and have the pedagogical skills to apply student-centered teaching methods like the project teaching method.

\section{References}

Akinbobola, A.O., Ikitde, G.A., (2011) Strategies for teaching mineral resources to Nigeria secondary school science students. African Journal of Social Research and Development, 3(2), 130-138.

Amaechi, O.J., Thomas, C.G., (2016) Strategies of effective teaching and learning practical skills in Technical and Vocational Training Programmes in Nigeria. International Journal of Scientific Research Engineering \& Technology (IJSRET), 5 (12) 598-603.

Andiema, N.C., (2016) Effect of child centered methods on teaching and learning of science activities in pre-schools in Kenya. Journal of Education and Practice, 7 (27), 1- 9.

Animezie, R., (2015) Effect of constructivist instructional method on students' achievement and understanding of physics in secondary school in Enugu Education Zone. Unpublished PhD dissertation, Department of Science and Computer Education, Enugu State University of Science and Technology, Nigeria. 
Ayonmike, C.H., (2014) Comparative effectiveness of lecture, demonstration and blended teaching methods on students' psychomotor performance in brick/block-laying and concreting in Delta State technical colleges. Unpublished PhD dissertation, Nnamdi Azikiwe University, Awka.

Bako, P.W., (2017) Effects of project and demonstration teaching methods on acquisition of brooding skills in poultry among students in Colleges of Education in Plateau State, Nigeria. Unpublished M.Sc thesis, Department of Vocational and Technical Education Ahmadu Bello University, Zaria, Nigeria.

Bala, B., (2006) Quantitative method for computing Student (An active learning approach), ADP Publication, London.

Basheer, A., Hugerat, M., Kortam, N., Hofstein, A., (2016) The effectiveness of teachers' use of demonstrations for enhancing students' understanding of and attitudes to learning the oxidation-reduction concept. EURASIA Journal of Mathematics Science and Technology Education, 13 (3) 555- 570. https://doi.org/10.12973/eurasia.2017.00632a

Biajone, J., (2006) Promoting positive attitudes towards statistics in pedagogy students through project work. In 7th International Conference on Teaching Statistics, State University of Campinas, Brazil.

Borich, G.D., (2011) Effective Teaching Methods: Research-Based Practice (7th ed.). Pearson Education, New York.

Dorgu, T.E., (2015). Different Teaching Methods: A Panacea for Effective Curriculum Implementation in the Classroom. International Journal of Secondary Education. 3(6-1), 77-87. https://doi.org/10.11648/j.ijsedu.s.2015030601.13

Ebonyi State Ministry of Education, (2018) NABTEB Result Grade sheets, 2010-2017. NABTEB, Printing Press, Abakaliki.

Eze, T.I., Ezenwafor, J.I., Molokwu, L.I., (2015) Effect of meta-learning teaching method on the academic performance of building trades students in technical colleges in South-east Nigeria, International Journal of Vocational and Technical Education, 7(10), 101-108, https://doi.org/10.5897/IJVTE2015. 0189

Federal Republic of Nigeria, F.R.N (2014). National Policy on Education, Government Printing Press, Lagos.

Himanshu, M., What is the demonstration method of teaching science?

Retrieved

from http://www.preservearticles.com/education/what-is-the-demonstration-method-ofteaching-science $/ 27824$

Horvath, K., (2011) Effects of peer tutoring on students' achievement, Ronard Publishers Ltd, Ohio.

Ikitde, G.A., Edet, U.B., (2013) Influence of learning styles and teaching strategies on students' achievement in Biology. Voice of Research, 1(4), 5-13.

Joshua, 0., (2015) Towards improving teaching of basic electricity/electronics in Technical Colleges in Bauchi State. ATBU, Journal of Science, Technology and Education (JOSTE), 3(2), 59- 62.

Kennedy, 0.0., (2011) Reappraising the work skill requirements for Building Technology Education in senior secondary school for Optimum performance in Nigeria, European Journal of Applied Sciences, 3(2), 46-52. 
Kpolovie, J.P., Joe, A.I., Okoto, T., (2014). Academic achievement prediction: role of interest in learning and attitude towards school, International Journal of Humanities Social Sciences and Education (IJHSSE) 1(11), 74- 100.

Leeds, E., Campbell, S., Baker, H., Ali, R., Brawley, D., Crisp, J., (2013) The impact of student retention strategies: an empirical study, International Journal of Management in Education, 7(1/2), 2243. https://doi.org/10.1504/IIMIE.2013.050812

Maizuwo, A.I., (2011) Effects of Demonstration Teaching Strategy in Remedying Misconceptions in Organic Chemistry among Students of Colleges of Education in Kano State, Unpublished M.Ed Thesis, Ahmadu Bello University, Zaria.

Muhammad, A.U., Bala, D., Ladu, K.M., (2016) Effectiveness of Demonstration and Lecture Methods in Learning Concept in Economics among Secondary School Students in Borno State, Nigeria, Journal of Education and Practice.7(12), 51-59.

NABTEB, (2012) Chief Examiner Report Available at: http://nabtebnigeria.org/wpcontent/uploads/2018/02/Chief-Examiners-Report-for-May-June-2012.pdf

National Business and Technical Examination Board. (2019) National Technical and Business Certificate Syllabus, Reviewed Edition, NBTE, Kaduna.

Nbina, J.B., Obomanu B.J., (2011) Assessment of the effects of problem-solving instructional strategies on students' achievement and retention in chemistry with respect to location in Rivers State, World Journal of Education, 1(2), 74-79.

Nsa, E.O., (2002) Effects of demonstration and project methods of teaching on senior secondary students' skill acquisition in vegetable production, Journal of Education Innovator, 1(1), 97-95

Ogbu, J.E., (2010) Benchmark on the teaching effectiveness of basic electricity teacher in south Eastern Nigeria, European Scientific Journal, 8(22), 299-326.

Ogbu, J.E., (2011) Effect of integrative application of interaction patterns on students' cognitive achievement in basic electricity, Journal of Science Teachers' Association of Nigeria, (46)1, 7181.

Ojimba, D.P., (2012) Vocational and Technical Education in Nigeria: Issues, Problems and Prospects' Dimensions (IPP), Journal of Educational and Social Research, 2(9), 23- 30. https://doi.org/10.5901/jesr.2012.v2n9p23

Okafor, M.N., (2014) Teaching Methods of Basic Electrical/Electronics in Technical Colleges, Special Books Ltd, Ibadan.

Olatoye, R. A., Adekoye, Y.M., (2010) Effect of project based, demonstration and lecture teaching strategies on senior secondary students' achievement in an aspect of Agricultural science, International Journal of Educational Research and Technology,1(1), 19-29.

Price, D.S., Brooks, D.W., (2012) Extensiveness and perceptions of lecture demonstrations in the high school chemistry classroom, Chemical Education Research and Practice, 13, 420-427. https://doi.org/10.1039/C2RP20014G

Robinson, N.R., (2017) Effectiveness of computer aided instructions (CAI) on students' performance in basic electricity in technical colleges in Rivers State of Nigeria, International Journal of Research -Granthaalayah, 5(11), 14-21. https://doi.org/10.5281/zenodo.1065704 
Saka-Alikinla, I., Owodunni A.S., Babatunde H.W., (2016) Comparative effects of structured and guided inquiry instructional techniques on students' academic achievement in basic electricity in Kwara State technical colleges, British Journal of Applied Science \&Technology, 14(6), 1-10.

Sola, O.A., Ojo, O.E., (2007). Effects of project, inquiry and lecture-demonstration teaching methods on senior secondary students' achievement in separation of mixtures practical test, Educational Research and Review, 2 (6), 124-132.

Thompson, J., Soyibo, K., (2012). Effects of lecture, teacher demonstrations, discussion and practical work on 10th graders attitudes to chemistry and understanding of electrolysis, Research in Science and Technological Education, 20(1), 25-37.

Umar, F., (2013) Demonstration method of teaching meaning, advantages \& disadvantages. http://www.studylecturenotes.com/curriculum-instructions/demonstration-method-ofteaching-meaning-advantages-disadvantages26/06/2019

Zakaria, A.B., Chine, S.K, David T.O., (2015) The Impact of Computer on the Performance of Students of Electricity in Colleges, Sparrow Publishers, California.

\section{Funding}

This study was not funded by any grant

\section{Conflict of interest}

The authors have no conflicts of interest to declare that they are relevant to the content of this article.

\section{About The License}

(C) The author(s) 2021 The text of this article is open access and licensed under a Creative Commons Attribution 4.0 International License 